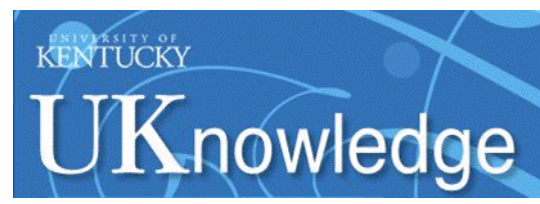

University of Kentucky

UKnowledge

9-2015

\title{
Evolution and Realms of Service Leadership and Leadership Models
}

Daniel T. L. Shek

University of Kentucky

Rachel C. F. Sun

University of Hong Kong, China

Ting Ting Liu

Wuhan University, China

Follow this and additional works at: https://uknowledge.uky.edu/pediatrics_facpub

Part of the Pediatrics Commons

Right click to open a feedback form in a new tab to let us know how this document benefits you.

\section{Repository Citation}

Shek, Daniel T. L.; Sun, Rachel C. F.; and Liu, Ting Ting, "Evolution and Realms of Service Leadership and Leadership Models" (2015). Pediatrics Faculty Publications. 207.

https://uknowledge.uky.edu/pediatrics_facpub/207

This Article is brought to you for free and open access by the Pediatrics at UKnowledge. It has been accepted for inclusion in Pediatrics Faculty Publications by an authorized administrator of UKnowledge. For more information, please contact UKnowledge@lsv.uky.edu. 


\section{Evolution and Realms of Service Leadership and Leadership Models}

Digital Object Identifier (DOI)

https://doi.org/10.1515/ijdhd-2015-0405

\section{Notes/Citation Information}

Published in International Journal on Disability and Human Development, v. 14, no. 3, p. 243-254.

(C) 2015 Walter de Gruyter GmbH, Berlin/Boston

The copyright holders have granted the permission for posting the article here. 


\section{Daniel T.L. Shek*, Rachel C.F. Sun and Ting Ting Liu Evolution and realms of service leadership and leadership models}

DOI 10.1515/ijdhd-2015-0405

Received April 7, 2014; accepted June 5, 2014; previously published online August 12, 2015

\begin{abstract}
This paper presents a lesson plan in a course entitled "Service Leadership" at The Hong Kong Polytechnic University. In that lecture, three basic aspects of the service leadership model are presented. First, the origin of service leadership from an evolutionary anthropology perspective is outlined. Second, three realms of service leadership with reference to self, others and systems are presented. Third, two leadership models (i.e. topdown and bottom-up models) are introduced, and their strengths and weaknesses are examined. Students are also invited to reflect on their assumptions of men with reference to leadership. Several class activities including role-play, self-reflection exercises and questionnaire survey are designed to help students achieve the learning outcomes. The paper ends by highlighting topics which can help students to have critical thinking and reflections.
\end{abstract}

Keywords: evolutionary anthropology; leadership models; realms of service leadership; service leadership model.

\section{Introduction}

Leadership is a universal phenomenon in societies with different economic, political or cultural characteristics

*Corresponding author: Daniel T.L. Shek, PhD, FHKPS, BBS, SBS, JP, Chair Professor of Applied Social Sciences, Faculty of Health and Social Sciences, Department of Applied Social Sciences, The Hong Kong Polytechnic University, Room HJ407, Core H, Hunghom, Hong Kong, P. R. China, E-mail: daniel.shek@polyu.edu.hk; Center for Innovative Programs for Adolescents and Families, The Hong Kong Polytechnic University, Hong Kong, P. R. China; Department of Social Work, East China Normal University, Shanghai, P. R. China; Kiang Wu Nursing College of Macau, Macau, P. R. China; and Division of Adolescent Medicine, Department of Pediatrics, Kentucky Children's Hospital, University of Kentucky College of Medicine, Lexington, KY, USA

Rachel C.F. Sun: Faculty of Education, The University of Hong Kong, Hong Kong, P. R. China

Ting Ting Liu: Department of Sociology, Wuhan University, Wuhan, P. R. China
$[1,2]$. Throughout history and in different societies, leadership has been continuously evolving in response to the adaptive challenges in the environment. In the last century, when industrialization was the major form of economic production, leadership was characterized by top-down and bureaucratic modes that serve the demands of a goods-producing economy requiring clear instructions in resource allocation and task assignment [3]. However, when society moves into a new age when service industries (e.g. financial, medical and welfare services) take the largest share in the economy, the relevance of the "traditional" leadership style is under great challenge. As such, there is a need to re-think the nature and meaning of leadership in the service era, particularly with reference to the service leadership model [4].

As proposed in the Hong Kong Institute of Service Leadership and Management (SLAM) curriculum framework, service leadership is about "satisfying needs by consistently providing quality personal service to everyone one comes into contact with, including one's self, others, communities, systems, and environments" and a service leader is "an on-the-spot entrepreneur who possesses relevant task competencies and is judged by superiors, peers, subordinates, and followers as having character and exhibiting care in action situations" [5, p. 5]. In addition to leadership knowledge and skills, the emphases on moral character and caring disposition in the service leadership model go beyond the existing conceptions of leadership by stressing the importance of leading oneself in addition to leading others. In addition, it can be considered an ecological model of leadership that can satisfy the needs of individuals, organizations and societies for sustainable development in a service economy. The belief underlying the model that Hong Kong's competitiveness and prosperity are tied to its citizens' ability to perform service leadership and service management also has many educational implications [5].

To fully understand the development of service leadership, an examination of leadership with reference to its historical origins, evolutionary mechanisms and significant features and advantages would be helpful. As "one of the world's oldest preoccupations" [6, p. 3], the history of leadership can be traced back to the origin of human society. From an evolutionary anthropology perspective, 
leadership is an outcome of natural selection [7]. In the complex process of social development, individuals who are confronted with various adaptive difficulties usually need to join up to respond to the challenges and achieve their shared goals, which results in the existence of leadership. More importantly, in the history of human adaptation, people also developed moral intuitions and service propensities, which are crucial to the successful survival of individuals and cooperative groups [5]. Basically, a group of people with diverse interests, intentions and habits can only survive and reach an optimum state of living with each other if the wellness of all members as a whole are maximized through the development of morality.

Haidt and Joseph [8] summarized five sets of basic human concerns, including harm/care, fairness/reciprocity, in-group/loyalty, authority/respect and purity/sanctity, each of which is linked to an adaptive challenge and one or more moral emotions. It was suggested that these five foundations of human intuitive ethics to some extent depict the way our ancestors lived. As moral issues are fundamental issues about how people ought to relate to each other [9], moral sense and service tendencies should be inherent in any kind of human life wherever two or more people are involved and naturally be basic concerns of leadership.

However, in the industrial age, where goods-focused thinking and goods-based business paradigms are prevailing, people's moral intuitions and service propensities are significantly undermined [5]. In many instances, mass production and profit-maximization at the expense of individual well-being and environmental conservation is not uncommon. Nowadays, when the Hong Kong economy has turned into a service-based structure and the environment is increasingly complex and fast-changing [10], the value of morality-related qualities and service qualities in impelling economic prosperity again becomes prominent. Hence, it is important to define leadership within a moral framework based on a service premise, which is in fact the original approach of leadership practice in human societies. According to the service leadership model, a core belief is that "service leadership is the world's oldest, most competitive, and longest surviving business model" [5].

According to the service leadership model, leadership is essentially a kind of service that can ethically satisfy the needs of targets in multiple ecological layers, including self, others, groups, communities, systems and environments [5]. By broadening the realms and redefining the nature of leadership, the service leadership model outperforms other leadership models in fitting the contemporary context that is featured by globalization, diversity, information explosion and service orientation. Traditional conceptions of leadership are usually confined to the individual level. As noted by Rost [11], leaders were usually those "great men and women with certain preferred traits who influence followers to do what the leaders wish in order to achieve group/organizational goals that reflect excellence defined as some kind of higher-order effectiveness" (p. 95). Under this model of leadership, coercive management strategies are preferred, and leaders' personal needs are met at the cost of followers' interests.

There are some advances in recent leadership theories that put their primary focus on collaborative relationships between leaders and followers as well as the empowerment of followers [12-14]. Even so, such changes are still inadequate as leaders themselves as targets of leadership/ service are generally forgotten. In reality, as asserted by Scharmer et al. [15], "an effective leader will have the capacity to use his or her Self as the vehicle-the blank canvas-for sensing, tuning in to, and bringing into presence that which wants to emerge" (p. 12). Some researchers even argue that the paramount tool for leading 21st-century change is the leader's self [16]. Paying similar attention to self-leadership, service leadership theorists suggest that self-leadership is an indispensable part of authentic leadership, and self-serving efforts should aim at ethically improving one's competencies, abilities and willingness to help satisfy the needs of others. In addition, service leadership takes into account the needs of environments and systems as well, regarding them as another realm of service leadership. This view was supported by Rost and Barker [17] who contended that in the postindustrial world, the concept of leadership must incorporate the complexities of social processes and the pluralistic nature of global society and "serve the general needs of society rather than the exclusive needs of corporations or of corporate executives" (p. 5).

Another important feature of the service leadership model is its focus on the strengths and potentials of individuals. Traditional leaders generally adopted a top-down hierarchical model in which influences only go from leader to subordinates rather than the opposite [10]. Although such a model proved useful in the past goods-dominant economy that preferred quantity to quality, result to process, efficiency to effectiveness and physical assets to social assets $[3,18]$, there is no place for authoritarian leadership in the present service- and knowledge-based society [19]. In contrast to the rigid mode of industrial production, a service economy typically displays high complexity, flux and diversity $[10,20]$, which requires organizations to be adaptive and flexible enough to survive 
Table 1: Rundown of the lecture.

\begin{tabular}{|c|c|c|}
\hline Activity & Procedures & Materials \\
\hline 1. Opening ( $5 \mathrm{~min})$ & $\begin{array}{l}\text { Opening: } \\
\text { - Recap lecture } 2\end{array}$ & Lecture PPT \\
\hline 2. Lecture (15 min) & Part I: History and evolutionary origin of service leadership & Lecture PPT \\
\hline 3. Role-play (25 min) & "Getting Back to the Ancient Era..." & $\begin{array}{l}\text { Lecture PPT } \\
\text { Appendix } 1\end{array}$ \\
\hline 4. Lecture (10 min) & Part II: Three realms of service leadership & Lecture PPT \\
\hline 5. Self-reflection exercise (15 min) & "My Leadership in Myself, Others, and Systems" & $\begin{array}{l}\text { Lecture PPT } \\
\text { Worksheet } 1\end{array}$ \\
\hline 6. Lecture $(10 \mathrm{~min})$ & Part III: Two models of service leadership: top-down and bottom-up & Lecture PPT \\
\hline 7. Class activity (15 min) & “Human Nature: How do I View?” & $\begin{array}{l}\text { Lecture PPT } \\
\text { Worksheet } 2\end{array}$ \\
\hline 8. Lecture (5 min) & Part IV: Advantages and disadvantages of the two models & Lecture PPT \\
\hline 9. Lecture (5 min) & $\begin{array}{l}\text { Part V: Conclusion } \\
\text { - Conclude the lecture }\end{array}$ & Lecture PPT \\
\hline 10. Sharing ( $5 \mathrm{~min})$ & $\begin{array}{l}\text { Sharing: } \\
\text { - Invite two students to share their thoughts after taking this lecture }\end{array}$ & \\
\hline
\end{tabular}

in such a context [21]. As knowledge workers who are creative, independent and active constitute the primary human resource in the new economy [22], it is necessary to allow those taking initiative in knowledge generation to share leadership regardless of their positions of formal authority [20]. Out of these concerns, service leadership advocates that a "maritime" leadership style, which combines both top-down and bottom-up models, in contrast to the "continental" style (i.e. top-down model only), is more productive, competitive, profitable and sustainable [5].

In short, the service leadership model proposed by the Hong Kong Institute of Service Leadership and Management is innovative because it focuses on leadership within the service economy context. With its emphases on moral character from an evolutionary anthropology perspective, ecological perspective and with a positive view about human beings, it provides an important alternative perspective on leadership. In this paper, a detailed lesson plan in a course titled "Service Leadership" is presented in which three basic aspects of service leadership, including its origins from an evolutionary anthropology perspective, realms of service leadership and the two models of leadership (bottom-up vs. top-down models) are highlighted. The course has 14 lessons in total, each lasts $2 \mathrm{~h}$, and the present lesson plan is Lecture Three.

\section{Overview of the lecture}

By tracing the evolutionary development of leadership in human society, this lecture introduces students to the origins of service leadership and contextualizes leadership in different historical, cultural and social settings. The importance of promoting service leadership in contemporary Hong Kong society is further highlighted. Then, three realms of service leadership (i.e. self, others and systems) and two leadership models (i.e. top-down and bottom-up) are elaborated with examples to help students understand the basic framework of service leadership and reflect on their personal acts and assumptions with reference to service leadership. The objectives of Lecture Three are to enable students to 1) understand the evolutional origin of leadership; 2) appreciate the importance of leadership in different socio-cultural contexts; 3) identify service leadership in the realms of self, others and systems; 4) recognize the pros and cons of top-down and bottom-up leadership styles; and 5) reflect on one's own behaviors and assumptions in relation to service leadership.

There are five parts of this lecture. These include 1) history and evolutionary origin of service leadership; 2) three realms of service leadership; 3) two models of service leadership - top-down and bottom-up; 4) advantages and disadvantages of the two models; and 5) conclusion. Three class activities have been designed for this lecture to facilitate students' learning in the forms of roleplay, self-reflection exercises and questionnaire survey. More details about the rundown are shown in Table 1.

\section{Content of the lecture. Part I: history and evolutionary origin of leadership}

Anthropological evidence suggests that leadership universally exists in all human societies [23]. Whenever a group 
of people gather, a leader-follower relationship naturally develops, even when the group tends to be leaderless $[7,24]$. Evolutionary theory implies that the emergence of leadership is a result of natural selection through which individual people coordinate their actions to cope with diverse challenges in the natural and social environments $[25,26]$. By determining the type, timing and duration of group activities, the formation of leader-follower relationships can facilitate group decision-making, directing the group toward a mutually expected direction [7]. The benefits of quality leadership can be simultaneously shared by both leaders, who are rewarded with more wealth and socioeconomic capital, and followers, who can make achievement more easily by virtue of collective effort $[25,27]$. Moreover, it was noted that the ways different selection pressures shape leadership are different. The development of leadership is normally fine-tuned to specific adaptive challenges [7].

There is an evolutionary viewpoint that leadership is a product of resource and status competitions in which leadership is interpreted as a sort of dominance of people who occupy higher positions over lower-ranked ones [28]. While this notion gives emphasis to the competences constituting the necessary qualities that a leader must possess, it underestimates the importance of social emotional intelligence such as morality, altruism, empathy, generosity and fairness in leadership, which more often serves as a coordination device that helps groups to respond to various problems [29]. As pointed out by Van Vugt, Hogan and Kaiser [25], "good leaders should be perceived as both competent and benevolent because followers want leaders who can acquire resources and then are willing to share them" (p. 190). The fierce intergroup competitions in the evolutionary history also created pressures for the development of a range of collectivistic traits as mentioned above that can significantly contribute to the group cohesion and competitiveness. Hence, service leadership is considered the world's oldest, most competitive and longest surviving business model during which people naturally evolved leadership together with moral intuitions and service propensities.

At the beginning of this part of the lecture, several pictures showing the nature of leadership as a universal phenomenon are shown to students. The instructor then leads students to look back on leadership wisdom developed in ancient human societies. Based on several examples of different types of leader (e.g. emperor, head of clan, military general), students are asked to think about whether leadership can be sustained without some sense of morality or service, which subsequently leads to the notion that service leadership is in fact the world's oldest surviving business model. Drawing on the insights of the evolutionary perspective, the instructor explains to students the evolutionary mechanisms of service leadership and eventually arrives at a conclusion that service leadership is in a sense the result of natural selection.

\section{Activity 1: getting back to the ancient era}

This activity is a role-play, scheduled at the end of Part 1 to facilitate students' understanding of the evolutional origins of different leadership forms. Three scenarios reflecting different human adaptive challenges in ancient times are assigned to students (see Appendix 1). Based on the scenarios they received, each group of students is requested to act out the described situations and how a leader emerges and behaves in such a context. Following students' performance, a discussion on what kind of leadership is required under what situations as well as reflections on whether leadership can benefit group behaviors are initiated in the class. The activity is wrapped up by concluding that different adaptive problems produce different forms of leadership and that leadership naturally develops where there is a group.

\section{Part II: three realms of service leadership}

As pointed out by Chung [5], human beings ordinarily maintain their fitness and survival and promote individual and group prosperities by thinking and behaving appropriately in three realms of relationships - individual, group and systems. Basically, the individual domain points to a person's intrapersonal relationship with self; the group domain denotes interpersonal relationships with other individuals and groups; the systems domain entails relationships with the general environment.

With reference to the specific situational contexts where the three realms of relationships take place, Chung [5] offered more explanations including that intrapersonal relationships occur within one's mind or body as well as places the individual operates in such as home and church; interpersonal relationships exist in places where two or more people interact and carry out service transactions (e.g. local offices, customer interaction arenas). Relationships with systems usually take place in communities where individuals, groups, and human created systems operate interactively in and via a variety of contexts (e.g. cities, nations). A brief summary of the three realms of service leadership is shown in Table 2. 
Table 2: Three realms of service leadership.

\begin{tabular}{|c|c|c|c|}
\hline & Self & Others & Systems \\
\hline Relationship & With self & With other individuals and groups & With systems and the environment \\
\hline Service & To one's self & To other people and groups & To systems and the environment \\
\hline Context & Within mind/body & In places where two or more people interact & $\begin{array}{l}\text { In communities where individuals, groups and } \\
\text { human-created systems operate interactively }\end{array}$ \\
\hline Sense & $\begin{array}{l}\text { Sense of personal } \\
\text { governance }\end{array}$ & Sense of influence, care and sharing & $\begin{array}{l}\text { Sense of influence on and contribution to } \\
\text { "things that happen to me" }\end{array}$ \\
\hline
\end{tabular}

According to the ecological systems theory, a person is embedded in a set of nested structures (e.g. family, school, community, society) that together constitute the ecological environment one lives in [30]. Development and changes are the outcome of interactions between the entity (e.g. human, family or school) and its environment [31]. The ecological perspective suggests that holistic and authentic leadership should act on all levels of the environment. Hence, self, others and environmental systems are considered three equally important realms a service leader needs to lead and serve.

In this part, the instructor first leads students to recap a figure shown in Lecture One, which represents multi-level contexts (i.e. self, others, community, society and environment) where a service leader operates. Then the contexts are categorized into three realms of service leadership, and detailed explanation is provided and summarized in a table. The instructor also gives examples (e.g. Mandela as a leader in systems) to help students understand how to perform service leadership in certain realms. At the end of this part, a classic Chinese proverb is introduced to call students' attention to a culture-specific interpretation.

\section{Activity 2: my leadership in myself, others and systems}

The second activity takes the form of a self-reflection exercise, the purpose of which is to help students reflect on their own service leadership in the three realms (i.e. self, others and systems) after learning Part 2. The concept that everyone can be a service leader whose behaviors contribute to the wellness of self and other people as well as the broader community or society is emphasized at the start of this session. Based on a worksheet (see Appendix 2), students are asked to identify at least one personal act in each of the realms and explain how these acts reflect service leadership in that realm. Upon completion of the worksheets, the instructor invites several students to share their experiences in class and encourages students to reflect on which realm(s) they want to improve further and what they plan to do.

\section{Part III: two models of leadership: top-down vs. bottom-up leadership}

How leaders and followers interact and what their consequences are have long been topics of great research interest. Although leadership was traditionally viewed as a hierarchical process by which people in higher positions influence their subordinate people to do what they wish them to do, a paradigm shift toward a simultaneous, ongoing, mutual influence process is increasingly advocated in recent works [32, 33]. These two styles of leadership often appear as dichotomies such as "top-down" vs. "bottom-up" leadership, "vertical" vs. "shared" leadership or "autocratic" vs. "democratic" leadership in existing literature [33-35].

There are many differences between these two models of leadership [20, 33, 36]. First, top-down leadership takes place through a unidirectional influence process, whereas bottom-up leadership flows through a collaborative process. Second, in top-down leadership the decisionmaking mechanism is rigid where leaders have full control. In contrast, decision-making is flexible where accountability is shared at all levels in bottom-up leadership. Third, whereas top-down leadership usually relies on authority, manipulation and coercion to achieve group goals, group goals are attained through members' commitment and collaboration in bottom-up leadership. Fourth, in top-down leadership, followers are not to be trusted but controlled, whereas the bottom-up model assumes that followers are independent, creative, dignified and trustworthy.

This part introduces the characteristics of the two leadership models. To facilitate students' comprehension of the models, two specific examples are provided. One is the former CEO of the HP company Fiorina, who is famous for her strict management of employees, and the other is the HCL company, whose philosophy is "employee first, customer second". Short films are played respectively to 
show their stories. Students are encouraged to share their observations after watching the videos.

\section{Activity 3: human nature: how do I view?}

This activity is designed as a follow-up exercise for Part 3. A questionnaire measuring perceptions of human nature is adopted (see Appendix 3) based on which students are expected to reflect on how these perceptions are related with their favored leadership styles (i.e. top-down or bottom-up). By calculating scores on each item, students can identify their own standpoints about human nature. After completing the questionnaire and scoring, the instructor invites a few students to share their scores or thoughts on this topic and also the leadership models they think are the most desirable. The activity is wrapped up with the instructor's interpretation of the relationship between one's human nature assumptions and preferred leadership style.

\section{Part IV: advantages and disadvantages of the two models}

Numerous studies have been conducted to investigate the outcomes of different models of leadership. After presenting the research findings, students are helped to understand that whether top-down or bottom-up leadership is effective is usually not a question. The question to be asked is in what contexts which kind of leadership should be adopted. For example, the relatively heavier emphasis on a collaborative approach of leadership shown in the current research field is framed under contemporary service-oriented socioeconomic settings $[3,10]$. As such, it is necessary to identify the advantages and disadvantages of each of the models, so that appropriate application of them is possible.

Briefly speaking, the advantages of top-down leadership are primarily reflected in the efficiency of decisionmaking and task accomplishment, maximized use of collective resources and effectiveness in group mobilization. However, this style of leadership may frustrate followers' motivation, suppress creative ideas of team members and create an environment of fear and resentment. With regard to the bottom-up model, while it is more effective in producing higher motivation and less stress, stimulating and facilitating creativity and innovation, and bringing empowerment in followers, such an approach may result in a loss of strategic focus in decision-making, particularly by the absence of overall rules, allow top leaders to evade responsibilities and promote the inconsistent application of policies [20,36,37]. In view of these pros and cons, service leadership theory recommends combining both top-down and bottom-up models to accommodate different situational requirements.

To inspire students' thinking, the instructor only shows the disadvantages of top-down leadership and the advantages of bottom-up leadership initially. The students are then encouraged to analyze the advantages of top-down model and disadvantages of bottom-up model. After students have some discussion, a model that combines the two models of leadership is recommended. Further illustrations are offered on how to choose leadership models in face of different situations, such as emergent situation and long-term decision-making.

\section{Part V: conclusion}

A brief summary is made of the information covered in the lecture. In addition, students are invited to identify which core beliefs this lecture is linked to for the purpose of strengthening their systematic understanding of the service leadership theory. This exercise would be set as a regular practice in the following lectures.

\section{Discussion}

A lecture regarding the understanding of service leadership in a history realm is presented above, and more content can be included to promote the critical thinking and reflection of students if time is available. First, more thoughts on the relationship between the evolutionary view of leadership under service leadership and its emphasis on moral character should be explored. If it is "survival of the fittest" that matters, which is essentially related to the "selfish gene", why is it necessary to talk about morality? Second, it would be interesting to encourage students to discuss the relative contribution of genetic and environmental influences on the shaping of leadership. How might "nature" and "nurture" contribute to the emergence of service leadership? Third, with reference to the three realms of leadership, it would be interesting to ask which realm is more important than the others. For example, with reference to Confucian thoughts, self-cultivation is the root of leadership, which precedes regulation of the family, ruling the country and governing the world [38]. However, sociologists and those theorists adopting a macro perspective focus on 
how the environment affects leadership. Finally, more thoughts should be spent on a discussion of the linkage between the "top-down" and "bottom-up" leadership qualities and assumptions of men. More negative views of human beings are associated with the "top-down" view, and more positive views of men are associated with the "bottom-up" views of men. In fact, students should be encouraged to explore their own assumptions about men and how these assumptions are linked to their views about leadership.

\title{
Appendix 1
}

\author{
THE HONG KONG POLYTECHNIC UNIVERSITY \\ DEPARTMENT OF APPLIED SOCIAL SCIENCES \\ APSS2820 Service Leadership \\ Lecture Three: History, Realms and Models
}

Role-play: Getting Back to the Ancient Era...

Cut-off the three scenarios along the dotted lines, and ask students to draw one from them for their groups, respectively. Request each group discuss how an effective leader should act in the situation they have drawn and then role-play the scenario collaboratively.

\section{Scenario A:}

The lasting rainstorm is putting the whole village in great danger of destructive flooding. The leader needs to find the tribe a new place to live and make sure all the villagers, including women and children, can move safely in the shortest time.

How should an effective leader act in this situation?

\section{Scenario B:}

There is a big tribe composed of dozens of households. Every day there are various conflicts among the tribe members. This time, Mike's cattle have eaten many crops at Simon's farmland, causing an intensifying dispute between the two families. The tribe leader has to deal with these kinds of conflicts every day and prevent trivial things from developing into big issues.

How should an effective leader act in this situation?

\section{Scenario C:}

The recent attacks from the neighboring tribe, who are trying to expand their territory, have caused huge losses and have posed a threat to the safety of your tribe. It is more and more difficult to protect your people from subsequent aggressions with passive defense.

\section{How should an effective leader act in this situation?}




\section{Appendix 2}

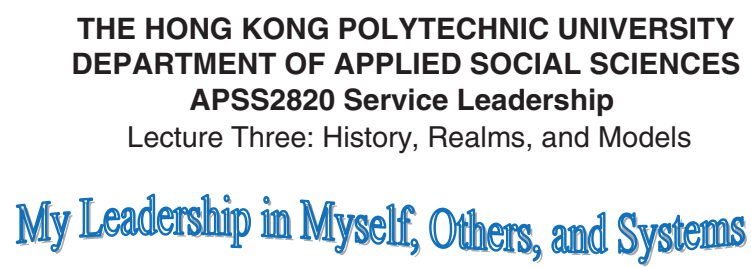

Try to identify at least one personal act you performed in the past that was in each of the three realms of leadership: self, others, and systems. Then briefly describe why this action is related to Service Leadership in that realm.

Leadership in myself

My act(s):

Why:

Leadership in other people

My act(s):

Why:

Leadership in systems

My act(s):

Why: 


\section{Appendix 3}

\section{THE HONG KONG POLYTECHNIC UNIVERSITY \\ DEPARTMENT OF APPLIED SOCIAL SCIENCES \\ APSS2820 Service Leadership \\ Lecture Three: History, Realms, and Models}

Human nature: How do I view?

Read the following items and choose the answer that best describes your beliefs about human nature in general. The numbers from one extreme ("1") to another extreme ("7") represent different levels of feelings. "4" means "neutral". Please try to avoid choosing a neutral answer.

\section{Part 1}

1. I believe people are

\begin{tabular}{ccccccc}
1 & 2 & 3 & $\begin{array}{c}4 \\
\text { (Neutral) }\end{array}$ & 5 & 6 & $\begin{array}{c}7 \\
\text { Completely rational }\end{array}$ \\
\hline
\end{tabular}

2. I believe people are

$\begin{array}{ccccccc}1 & 2 & 3 & 4 & 5 & 6 & \begin{array}{c}7 \\ \text { Completely } \\ \text { Completely free }\end{array} \\ & & \text { (Neutral) } & & & \begin{array}{c}\text { determined by genes } \\ \text { and environment }\end{array}\end{array}$

3. I believe people are

\begin{tabular}{ccccccc}
1 & 2 & 3 & 4 & 5 & 6 & 7 \\
Completely proactive & & & (Neutral) & & & Completely reactive \\
\hline
\end{tabular}

4. I believe people are

\begin{tabular}{crrrrrr}
1 & 2 & 3 & 4 & 5 & 6 & 7 \\
Completely changeable & & & $($ Neutral) & & & Completely unchangeable \\
\hline
\end{tabular}

5. I believe people are

\begin{tabular}{ccccccc}
1 & 2 & 3 & 4 & 5 & 6 & 7 \\
Has much worth & & & (Neutral) & & & Completely worthless \\
\hline
\end{tabular}

6. I believe people are

$\begin{array}{lllllll}1 & 2 & 3 & 4 & 5 & 6 & 7\end{array}$

Non-sinful (morally good)

(Neutral)

Sinful (morally bad)

7. I believe people are

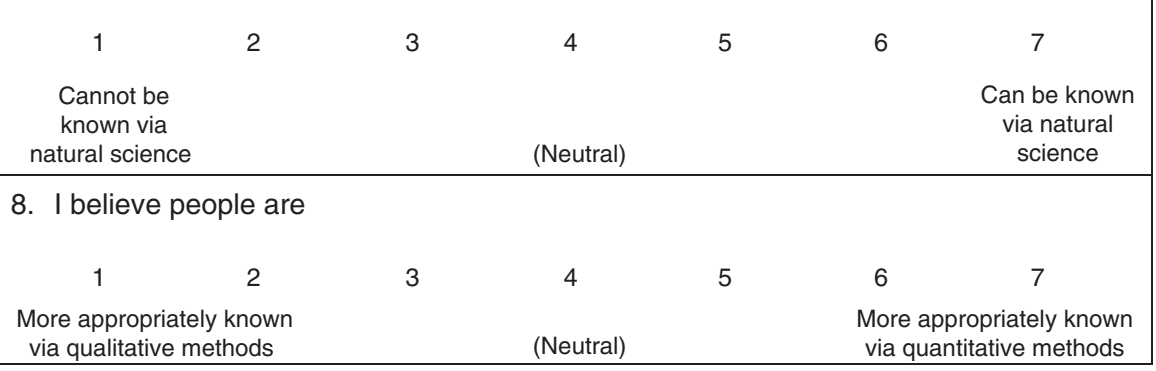




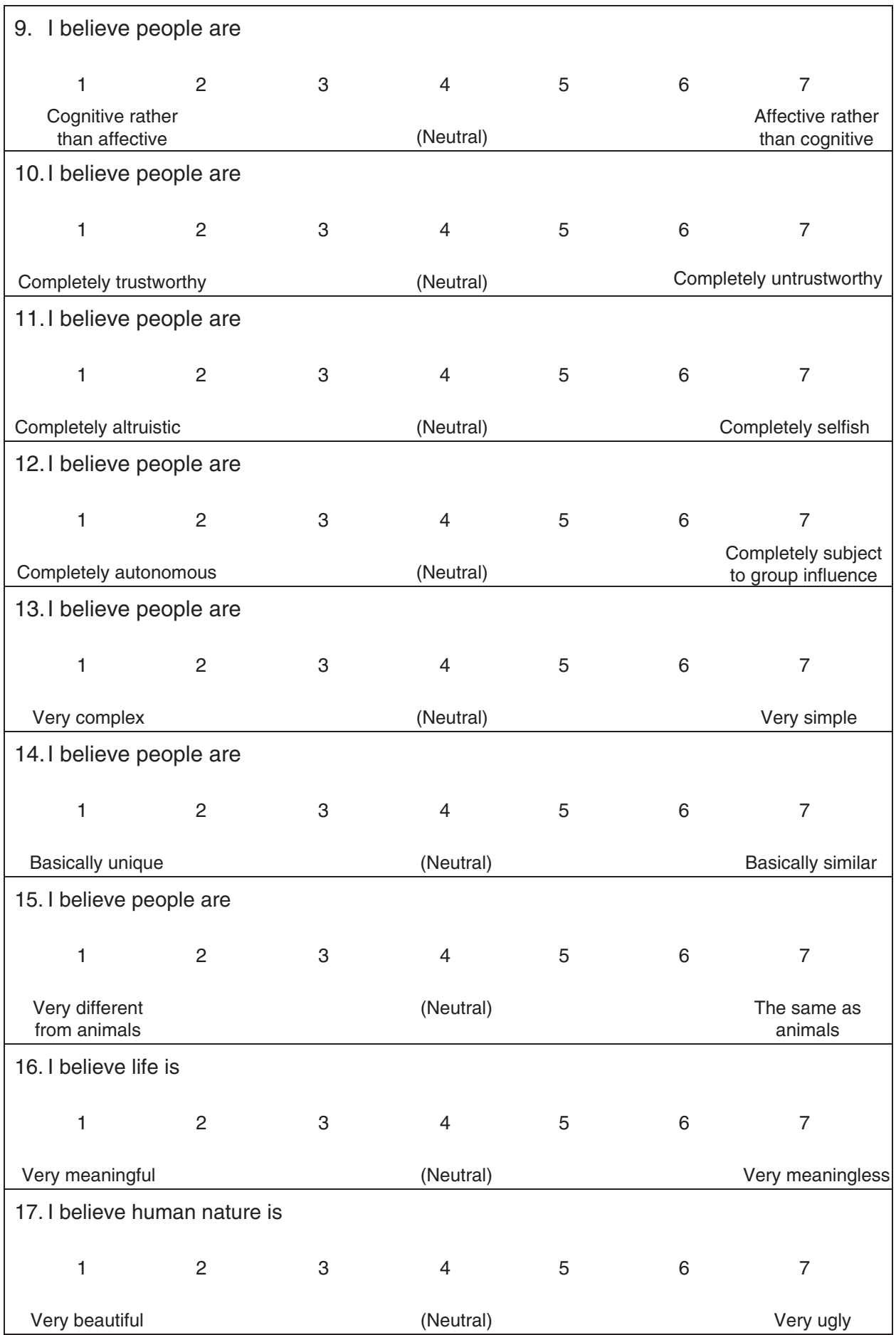




\section{Part 2}

1. To understand human behavior, we should

2

3

4

5

6

7

Be holistic to

understand others

(Neutral)

Understand others by dividing them into simple elements (such as genes or components)

2. In the process of understanding human being, I believe understanding other's subjective feeling is

\begin{tabular}{|llcccc|}
\hline 1 & 3 & 4 & 6 & 7 \\
Very important & (Neutral) & & & Not important \\
\hline $\begin{array}{l}\text { 3. I believe that the aim of human behavior is } \\
1\end{array}$ & 3 & 5 & 6 & 7 \\
$\begin{array}{c}\text { To purse new feeling, } \\
\text { and transcend the } \\
\text { current spiritual states }\end{array}$ & 4 & & $\begin{array}{c}\text { To attain spiritual } \\
\text { balance }\end{array}$ \\
\hline
\end{tabular}

Source: Shek DTL, Lau PSY, Lam CM, Cheung KS, Chak YL, Y Wong CS, et al. (editors) (2007). P.A.T.H.S. to Adulthood: A Jockey Club Youth Enhancement Scheme. Secondary two curriculum (full implementation phase): Training workshop resource kit and CD. Hong Kong: Social Welfare Practice and Research Centre, Department of Social Work, The Chinese University of Hong Kong.

\section{What are your scores?}

Part 1

Part 2

\section{References}

1. Bass BM, Bass R. The Bass handbook of leadership: theory, research, and managerial applications. New York, NY: Free Press, 2008.

2. Brown DE. Human universals. New York: McGraw-Hill, 1991.

3. Uhl-Bien M, Marion R, McKelvey B. Complexity leadership theory: shifting leadership from the industrial age to the knowledge era. Leadership Quart 2007;18:298-318.

4. Shek DT, Yu L, Ma CM, Sun RC, Liu TT. Development of a creditbearing service leadership subject for university students in Hong Kong. Int J Adolesc Med Health 2013;25:353-61.

5. Chung P. Hong Kong Institute of Service Leadership and Management curriculum framework. Hong Kong: Hong Kong Institute of Service Leadership and Management, 2011.

6. Bass BM. Bass and Stogdill's handbook on leadership: theory, research and managerial implications. New York, NY: Free Press, 1990.

7. Van Vugt M. Evolutionary origins of leadership and followership. Pers Soc Psychol Rev 2006;10:354-71.

8. Haidt J, Joseph C. The moral mind: how five sets of innate intuitions guide the development of many culture-specific virtues, and perhaps even modules. In: Carruthers P, Laurence S, Stich S, editors. The innate mind: foundations and the future. New York, NY: Oxford University Press, 2008:367-92.

9. Turiel E. The development of social knowledge: morality and convention. Cambridge: Cambridge University Press, 1983.

10. Allen KE, Stelzner SP, Wielkiewicz RM. The ecology of leadership: adapting to the challenges of a changing world. J Leadership Organ Stud 1999;5:62-82.

11. Rost JC. Leadership for the twenty-first century. Westport, MA: Praeger, 1993.

12. Rost JC. Moving from individual to relationship: a postindustrial paradigm of leadership. J Leadership Organ Stud 1997;4:3-16.

13. Gibney J, Copeland S, Murie A. Toward a 'new' strategic leadership of place for the knowledge-based economy. Leadership 2009;5:5-23.

14. Brungardt CL. The new face of leadership: implications for higher education. Available at: http://www.nwlink. com/ donclark/leader/lead_edu.html. Accessed: 2 Sep 2013.

15. Scharmer CO, Arthur WB, Day J, Jaworski J, Jung M, Nonaka I, et al. Illuminating the blind spot: leadership in the context of emerging worlds. Available at: http://www.ottoscharmer. com/docs/articles/2002_Illuminating_the_Blind_Spot.pdf. Accessed: 4 Sep 2013. 
16. Sydänmaanlakka P. Intelligent leadership and leadership competencies: developing a leadership framework for intelligent organizations. Available at: https://aaltodoc.aalto.fi/ handle/123456789/2042. Accessed: 4 Sep 2013.

17. Rost JC, Barker RA. Leadership education in colleges: toward a 21st century paradigm. J Leadership Organ Stud 2000;7:3-12.

18. Jones GR. Organizational theory, 3rd ed. Reading: AddisonWesley, 2000.

19. Dentico JP. Games leaders play: using process simulations to develop collaborative leadership practices for a knowledgebased society. Career Dev Int 1999;4:175-82.

20. McCrimmon M. Bottom-up leadership. Executive Dev 1995; 8:6-12.

21. Collier J, Esteban R. Systemic leadership: ethical and effective. Leadership Organ Dev J 2000;21:207-15.

22. Brinkley I. Defining the knowledge economy: knowledge economy programme report. London: Work Foundation, 2006.

23. Boehm C. Hierarchy in the forest: the evolution of egalitarian behavior. London: Harvard University Press, 2009.

24. Bass BM. The leaderless group discussion. Psychol Bull 1954:51:465-92.

25. Van Vugt M, Hogan R, Kaiser RB. Leadership, followership, and evolution: some lessons from the past. Am Psychol 2008;63:182-96.

26. Smith KB, Larimer CW, Littvay L, Hibbing JR. Evolutionary theory and political leadership: why certain people do not trust decision makers. J Polit 2007;69:285-99.

27. Hogan R, Curphy GJ, Hogan J. What we know about leadership: effectiveness and personality. Am Psychol 1994;49:493-504.
28. Wilson EO. Sociobiology: the new synthesis. Cambridge, MA: Harvard University Press, 1975.

29. Gillet J, Cartwright E, Vugt Mv. Selfish or servant leadership? Evolutionary predictions on leadership personalities in coordination games. Pers Individ Dif 2011;51:231-6.

30. Bronfenbrenner U. Ecological systems theory. In: Vasta R, editor. Six theories of child development: revised formulations and current issues. London: Jessica Kingsley Publishers, 1992:187-249.

31. Chibucos TR, Leite RW, Weis DL. Readings in family theory. Thousand Oaks, CA: Sage, 2005.

32. Pearce CL. The future of leadership: combining vertical and shared leadership to transform knowledge work. Acad Manage Exec 2004;18:47-57.

33. Ensley MD, Hmieleski KM, Pearce CL. The importance of vertical and shared leadership within new venture top management teams: implications for the performance of startups. Leadership Quart 2006;17:217-31.

34. Gastil J. A meta-analytic review of the productivity and satisfaction of democratic and autocratic leadership. Small Gr Res 1994;25:384-410.

35. Borins S. Leadership and innovation in the public sector. Leadership Organ Dev J 2002;23:467-76.

36. Vroom VH, Yetton PW. Leadership and decision-making. Pittsburgh: University Pittsburgh Press, 1973.

37. Johnson HT. Relevance regained: from top-down control to bottom-up empowerment. New York: Free Press, 1992.

38. Shek DT, Yu L, Fu X. Confucian virtues and Chinese adolescent development: a conceptual review. Int J Adolesc Med Health 2013;25:335-44. 